\title{
PEMASARAN POLIS ASURANSI PRUDENTIAL DALAM UPAYA MENINGKATKAN PENJUALAN
}

\author{
Darmansah, Imam Asrori, Leli Marcela \\ Fakultas Ilmu Sosial dan Ilmu Politik Universitas Kapuas Sintang \\ darmansah17@gmail.com \\ Universitas Kapuas Sintang, Jln. Oevang Oeray No. 92 Sintang Kalimantan Barat
}

\begin{abstract}
Abstrak : Cabang PT. Prudential Pru.Victory Kecamatan Sintang salah satu perusahaan yang bergerak dibidang asuransi. Dalam upaya meningkatkan penjualannya polis asuransinya di Kecamatan Sintang khususnya serta Di Kabupaten Sintang pada umumnya menggunakan beberapa Strategi pemasaran. Strategi pemasaran tersebut dikasanakan oleh Agen/Konsultan asuransi perusahaannya. Jenis penelitian ini adalah deskriptif dengan pendekatan kualitatif. Pengumpulan data yang digunakan dengan menggunakan wawancara, studi dokumentasi dan observasi. Kajian dalam penelitian ini untuk mengetahui "Strategi Pemasaran Polis Asuransi Prudential Dalam Upaya meningkatkan Penjualan Di Kecamatan Sintang KabupatenSintang denagan aspek penelitiannya adalah :tentang produk asuransi, Harga Premi, Promosi, Tempat, Orang dan Sarana Fisik. Hasil penelitian menunjukkan bahwa Cabang PT. Prudential Pru. Victory Kecamatan Sintang telah dapat menjalankan strategi pemasaran yang dibuat dan ditetapkan oleh perusahaannya melalui beberapa pola yaitu menggerakan agen/konsultannya secara maksimal dilapangan dengan pengetahuan yang memadai tentang produk serta manfaat asuransi sehingga memiliki kemampuan menjelaskannya kepada calon nasabah/calon konsumen dan pola pemasaran secara Online melalui website perusahaan yang dipromosikan melalui berbagai media elektronik. Adapun teknis pemasaran berbagai jenis asuransi yang dimiliki perusahaan yaitu dilakukan dengan cara menggerakan agen/konsultan berkunjung dari rumah ke rumah (door to door). masyarakat yang telah dijadikan sasaran agen/konsultas sebelumnya. Teknis kedua yakni mengadakan pertemuan dengan kelompok orang baik di Kantor-kantor maupun di perusahaan-perusahan perkebunan dan lembaga ekonomi lainnya sehingga penjualan polis dapat dilakukan secara kolektif. Dengan demikian perusahaan Cabang PT. Prudential Pru. Victory Kecamatan Sintang berhasil meningkatkan penjualan polis asuransi dari tahun sebelumnya yakni tahun 2017. Kesimpulan hasil penelitian yakni dengan adanya Strategi pemasaran dengan mendatangi calon nasabah dari rumah ke rumah (door to door) mengadakan pemasaran kepada banyak orang sekaligus diberbagai instansi maupun perusahaan maka perusahaan asuransi Prudential Kecamatan Sintang berhasil secara bertahap dari tahun ke tahun meningkatkan penjualan polis asuransi sejak dari tahun 2015-2018 yang lalu.
\end{abstract}

Kata Kunci : Strategi, Pemasaran, Polis Asuransi.

Dewasa ini perubahan dan berbagai kondisi yang terjadi dalam lingkungan bisnis internasional akan berdampak dalam meningkatnya persaingan. Hal ini menggerakkan perusahaan harus dapat bersaing dengan strategi yang efektif untuk mencapai daya saing yang strategis dan menghasilkan keuntungan yang maksimal. Perusahaan asuransi memberikan kontribusi yang signifikan dalam pertumbuhan perekonomian Indonesia dengan menawarkan konsep perlindungan investasi dan kesehatan yang berguna untuk meningkatkan kemampuan manajemen keuangan yang baik bagi kehidupan individu maupun rumah tangga masyarakat Indonesia.

PT Prudential Life Assurance (Prudential Indonesia) kemudian masuk ke Indonesia pada tahun 1995 yang merupakan perusahaan asuransi jiwa terkemuka di Indonesia dan merupakan bagian dari Prudential Plc Grup jasa keuangan yang berbasis di Inggris. Asuransi Prudential merupakan produk dari Perusahaan Prudential plc, perusahaan Multi Nasional Corporation yang merupakan sebuah grup jasa keuangan internasional terkemuka Inggris yang menyediakan jasa keuangan ritel dan pengelolaan dana di pasar-pasar pilihan, seperti Inggris, Amerika, Asia dan Eropa Kontinen Di inggris, Prudential adalah penyedia jasa asuransi jiwa dan dana pensiun terkemuka yang menawarkan berbagai produk keuangan ritel. $M \& G$ adalah pengelola dana Prudential di Inggris dan Eropa, yang mengelola dana lebih dari US\$ 330 milyar. Di Asia, Prudential adalah Perusahaan Asuransi Jiwa terkemuka dari Eropa yang memiliki jaringan bisnis yang Tersebar di 12 negara yaitu Cina, Hong Kong, India, Indonesia, Jepang, Korea, 
Malaysia, Filipina, Singapura, Taiwan, Thailand dan Vietnam. 2 Dengan memanfaatkan pengalaman Grup Prudential selama 165 tahun di industri asuransi jiwa, Prudential Indonesia berkomitmen untuk menyediakan solusi investasi terbaik, tabungan dadan solusi proteksi asuransi yang paling baik kepada nasabah di Indonesia. Sejak peluncuran produk asuransi yang terkait produk investasi pertamanya di tahun 1999, Prudential Indonesia telah menjadi pemimpin pasar untuk kategori produk inovatif ini. Prudential Indonesia juga menawarkan variasi produk dan layanan yang dirancang untuk memenuhi kebutuhan keuangan para nasabah Indonesia yang beragam. Sebagai pemimpin pasar, Prudential Indonesia selalu berusaha untuk menyediakan produk unit link yang dirancang untuk memenuhi dan melengkapi kebutuhan nasabahnya, dalam setiap tahap kehidupan, mulai dari usia kerja, pernikahan, kelahiran anak, pendidikan anak, dan masa pensiun. Di Kalimantan Barat juga dibuka beberapa Cabang PT. Prudential seperti di Kota Pontianak dan hampir seluruh Ibu kota Kabupaten di Kalimantan Barat Ttermasuk di Kabupaten Sintang telah berdiri Kantor Cabangnya pada tanggal 15 Juli 2013 Kantor Cabangnya beralamat di Jalan Kelam Tugu Beji Ruko No. 04 Kecamatan Sintang. Nama Kantor Cabangnya “PT. Prudential Pru Vitory”.

Adapun produk asuransi prudential yang ditawarkan untuk di Kabupaten Sintang hingga saat ini yaitu Asuransi Kesehatan, Asuransi Sakit Kritis, Asuransu dana pension, Asuransi Kecelakaan, Asuransi Komplit/Gabungan dari beberapa jenis Asuransi tersebut diatas. Dari semua jenis produk yang telah di pasarkan dimaksud, kuantitas penjualannya relatif adanya kenaikan dalam 3 (tiga) tahun terakhir ini, namun demikian angka penjualannya belum mencapai target seperti yang diharapkan oleh perusahaan yang dikarenakan oleh beberapa faktor seperti pemahaman masyarakat tentang manfaat Asuransi masih rendah, informasi yang diperoleh masyartakat tentang keberadaan Asuransi Prudential di Kabupaten Sintang pada umumnya masih minim dan pengetahuan masyarakat tentang keuntungan menjadi nasabah asuransi

Masih banyak persepsi seperti menabung di Bank dan lembaga keuangan lainnya. Selama ini pemasaran produk asuransi PT. Prudential di Kabupaten Sintang pada umumnya dan di Kecamatan Sintang khususnya dilakukan oleh perusahaan dengan menggunakan sosialisasi dengan berbatgai pertemuan baik bersifat bulanan maupun triwulan ataupun setiap enam bulan sekali. Selain itu juga pemasarannya juga dilakukan oleh
Agen PT. Prudential Sintang secara dor to dor (dari rumah ke Rumah), termasuk juga dipasarkan melalui brosur serta berbagai media baik itu media cetak maupun ia elektronik dengan sistem online. Dari permasalahan seperti yang telah diungkapkan atas maka penulis merasa tertarik untuk melakukan penelitian dengan judul : "Strategi Pemasaran Polis Asuransi Prudential Dalam Upaya Meningkatkan Penjualan Di Kecamatan Sintang Kabupaten Sintang". Adapun tujuan dari penelitian ini adalah untuk mengetahui, memahami dan menganalisa tentang Strategi Pemasaran Polis Asuransi Prudential Dalam Upaya Meningkatkan Penjualan Di Kecamatan Sintang Kabupaten Sintang.

Manajemen pemasaran dikelompokkan dalam empat aspek yang sering dikenal dengan marketing mix atau bauran pemasaran. Menurut Kotler \& Armstrong (1997:172) "bauran pemasaran (marketing mix) adalah kumpulan alat pemasaran taktis terkendali yang dipadukan perusahaan untuk menghasilkan respon yang diinginkannya di pasar sasaran”. Kotler\&Armstrong (1997:176) mengemukakan bahwa "pendekatan pemasaran 4P yaitu product, price, place dan promotion sering berhasil untuk barang, tetapi berbagai elemen tambahan memerlukan perhatian dan sistem distribusi". Sedang Boom\&Bitner dalam Kotler\&Armstrong (1997: 179) menyarankan "untuk menambah 3P yang terlibat dalam pemasaran jasa, yaitu: people (orang), physical evidence (bukti fisik), dan process (proses)". Sebagaimana telah dikemukakan oleh Kotler, Boom\&Bitner dalam Kotler\&Armstrong (1997: 179) di atas, Yazid (1999:55), menegaskan bahwa "marketing mix untuk jasa terdiri dari 7P, yakni: product (produk), price (harga), place (tempat), promotion (promosi), people (orang), physical evidence (bukti fisik), dan process (proses)".

Pengertian produk ( product) menurut Kotler \& Armstrong (1997: 188) adalah: "segala sesuatu yang dapat ditawarkan kepasar untuk mendapatkan perhatian, dibeli, digunakan, atau dikonsumsi yang dapat memuaskan keinginan atau kebutuhan. Secara konseptual produk adalah pemahaman subyektif dari produsen atas sesuatu yang bisa ditawarkan sebagai usaha untuk mencapai tujuan organisasi melalui pemenuhan kebutuhan dan kegiatan konsumen, sesuai dengan kompetensi dan kapasitas organisasi serta daya beli pasar. Selain itu produk dapat pula didefinisikan sebagai persepsi konsumen yang dijabarkan oleh produsen melalui hasil produksinya. Produk dipandang penting oleh konsumen dan dijadikan dasar pengambilan keputusan pembelian. 
Sedangkan Tjiptono (2008: 155) mengungkapkan bahwa "produk adalah pemahaman subyektif dari produsen atas sesuatu sebagai usaha untuk memenuhi kebutuhan dan keinginan konsumen".Tingkatan Produk menurutKotler \& Armstrong (1997 : 211) :Dalam merencanakan produk atau apa yang hendak ditawarkan ke pasar, para pemasar perlu berpikir melalui lima tingkatan produk dalam merencanakan penawaran pasar. Lima tingkatan produk tersebut terdiri dari: a. Manfaat Inti (core benefit) yaitu jasa atau manfaat fundamental yang benarbenar di beli oleh pelanggan. Misal: kasus hotel, dimana tamu hotel membeli "istirahat dan tidur". b. Produk dasar (basic product). Para pemasar harus mengubah manfaat inti menjadi produk generik (generic product), yaitu versi dasar dari produk tersebut. Dengan demikian sebuah hotel akan terdiri dari gedung dengan kamar-kamar yang disewakan. c. Produk yang diharapkan (expected product). Sekumpulan atribut dan kondisi yang biasanya diharapkan dan disetujui oleh pembeli ketika mereka membeli produk tersebut. Misal: tamu hotel mengharapkan ranjang yang bersih, sabun dan handuk, lemari pakaian, dan suasana yang tenang. d. Produk yang ditingkatkan (augmented product). Layanan dan manfaat tambahan yang membedakan penawaran perusahaan dari penawaran pesaing. Misal: sebuah hotel dapat melengkapi produknya dengan menambahkan seperangkat televisi, shampo, pemesan kamar yang cepat, makan malam yang lezat. e. Produk yang potensial (potensial product). Mencakup semua peningkatan dan transformasi yang akhirnya akan dialami produk tersebut dimasa depan. Klasifikasi produk bisa dilakukan atas berbagai macam sudut pandang.

Berdasarkan daya tahan atau berwujud tidaknya, produk diklasifikasikan ke dalam tiga kelompok Tjiptono (2008 : 188) : yaitu: 1)Barang tidak tahan lama ( No durable Goods). Barang tidak tahan lama adalah barang berwujud yang biasanya habis di konsumsi dalam satu atau beberapa kali pemakaian. 2) Barang tahan lama (Durable Goods) Barang tahan lama merupakan barang berwujud yang biasanya bisa bertahan lama dengan banyak perusahaan. 3) Jasa (Service) Jasa merupakan aktivitas, manfaat atau kepuasan yang ditawarkan untuk dijual. Dari definisi diatas dapat diambil kesimpulan bahwa produk adalah segala sesuatu yang ditawarkan oleh seseorang atau organisasi yang mempunyai manfaat, baik berupa benda nyata maupun benda abstrak atau tidak berwujud yang tujuannya 9 untuk memuaskan keinginan dan kebutuhan konsumen. Produk yang ditawarkan oleh perusahaan hendaknya adalah sebuah produk yang menarik, mempunyai penampilan bentuk fisik yang bagus dan yang lebih dikenal mudah diucapkan, dikenali dan diingat dan sebagainya.

Menurut Tjiptono (2008 : 221) : menyatakan bahwa harga dapat diungkapkan dengan beberapa istilah, misalnya tarif, sewa, bunga, premium, komisi, upah, gaji dan sebagainya. Dari sudut pandang pemasaran, harga merupakan satuan moneter atau ukuran lainnya (termasuk barang dan jasa) yang ditukarkan agar memperoleh hak kepemilikan atau penggunaan suatu barang atau jasa. Harga merupakan satusatunya unsur bauran pemasaran yang memberikan pemasukan atau pendapatan bagi perusahaan, sedangkan ketiga unsur lainnya adalah (produk, distribusi, dan promosi) menyebabkan timbulnya biaya (pengeluaran). Disamping itu harga merupakan unsur bauran yang bersifat fleksibel, artinya dapat diubah dengan cepat.

Sedangkan menurut Alma, (2003 : 55) Menyatakan bahwa : produsen harus pandai menetapkan kebijaksanaan harga, tinggi atau rendahnya harga yang ditetapkan harus berpedoman pada : a) Keadaan/kualitas barang, b) Konsumen yang dituju, berpenghasilan tinggi, sedang, atau rendah, konsumen perkotaan atau pedesaan, c) Suasana pasar, apakah produknya baru dikenalkan ke pasar atau produk menguasai pasar, produk sudah melekat dihati konsumen atau banyak saingan. Promosi merupakan salah satu faktor penentu keberhasilan suatu program pemasaran Tjiptono (2008:201): mengungkapkanbahwa promosi adalah semua kegiatan yang dimaksudkan untuk menyampaikan atau mengkomunikasikan suatu produk kepada pasar sasaran, untuk memberi informasi tentang keistimewaan, kegunaan dan yang paling penting adalah tentang keberadaannya, untuk mengubah sikap ataupun untuk mendorong orangorang supaya bertindak.

Bauran Promosi pemasaran menurut Tjiptono (2008 : 205) : Terdiri dari lima macam yaitu: a) Personal Selling Komunikasi langsung (tatap muka) antara penjual dan calon pelanggan untuk memperkenalkan suatu produk kapada calon pelanggan dan membentuk pemahaman pelanggan terhadap produk sehingga mereka kemudian akan mencoba dan membelinya. b) Mass Selling Merupakan pendekatan yang menggunakan media komunikasi untuk menyampaikan informasi kepada khalayak ramai. Mass Selling terdiri dari: 1) Periklanan Iklan adalah bentuk komunikasi tidak langsung, yang didasari pada informasi tentang keunggulan atau keuntungan 
suatu produk, yang disusun sedemikian rupa sehingga menimbulkan rasa menyenangkan yang akan mengubah pikiran orang untuk membeli. 2) Publisitas. Publisitas adalah bentuk penyajian dan penyebaran ide barang dan jasa secara non personal. 3) Sales Promotion Sales promotion adalah bentuk persuasi langsung melalui penggunaan berbagai insentif yang dapat diatur untuk merangsang pembelian produk dengan segera atau meningkatkan jumlah barang yang dibeli pelanggan. 4) Publik Relation Publik relation merupakan upaya komunikasi menyeluruh dari suatu organisasi untuk mempengaruhi persepsi, opini, keyakinan dan sikap berbagai kelompok terhadap organisasi tersebut. 5) Direct Marketing Direct marketing adalah sistem pemasaran yang bersifat interaktif yang memanfaatkan satu atau beberapa media iklan untuk menimbulkan respon yang terukur atau transaksi di sembarang lokasi.

Kotler\&Amstrong(1997:178) menyatakan bahwa perusahaan harus membagi anggaran promosi total untuk alat-alat promosi utama yaitu perikanan, penjualan perorangan, promosi penjualan dan hubungan masyarakat. Perusahaan harus secara hati-hati menetapkan besarnya masingmasing alat promosi menjadi bauran promosi yang terkoordinasi”.

Menurut Kotler\&Amstrong (1997:180) : faktor-faktor yang mempengaruhi pengembangan bauran promosi yaitu: a) Tipe Produk atau Pasar Perbedaan alat promosi bervariasi antara pasar konsumen dan pasar industri. Perusahaan barang konsumen biasanya mengalokasik hubungan dengan masyarakat. Sebaliknya perusahaan barang industri menyediakan dana lebih banyak untuk penjualan perorangan diikuti dengan promosi penjualan, iklan, dan hubungan dengan masyarakat. b) Strategi Dorong dan Tarik Strategi dorong merupakan strategi promosi yang menggunakan tenaga penjual dan promosi perdagangan untuk mendorong produk lewat saluran distribusi. Sedangkan strategi tarik adalah strategi promosi yang menggunakan banyak biaya untuk periklanan dan promosi konsumen demi memupuk permintaan konsumen. c) Tahap Kesiapan pembeli pengaruh dari alat promosi bervariasi untuk tahap kesiapan pembeli yang berbeda. Iklan, bersama dengan hubungan masyarakat, lebih memegang peran utama dalam tahap kesadaran dan pengetahuan, ketimbang peran "kunjungan mendadak" dari tenaga penjual. d) Tahap Daur Hidup produk Pengaruh dari alat promosi yang berbeda juga bervariasi sesuai dengan tahap daur hidup produk. Tahap pengenalan, iklan dan hubungan masyarakat baik untuk menghasilkan kesadaran tinggi, promosi penjualan bermanfaat untuk mempromosikan penjualan awal. Tahap pertumbuhan, iklan dan hubungan masyarakat terus memberikan pengaruh kuat, sedangkan promosi penjualan dapat dikurangi. Tahap ewasa, promosi penjualan menjadi relatif penting dibandingkan dengan iklan. Place (Tempat) menurut Alma, (2003: 57) berarti "kemana tempat/ lokasi yang dituju, bagaimana saluran distribusinya, berapa banyak saluran, dan kondisi para penyalur yang diperlukan". Kotler \& Amstrong ( 1997 : 182) mengungkapkan bahwa "saluran distribusi adalah suatu perangkat organisasi yang saling tergantung dalam menyediakan satu produk atau jasa untuk digunakan atau dikonsumsi oleh konsumen atau pengguna bisnis". Sedangkan Kotler (1997: 189) mendefinisikan "saluran distribusi adalah serangkaian organisasi yang saling tergantung dan terlibat dalam proses untuk menjadikan suatu produk atau jasa siap digunakan untuk konsumsi”. Menurut Kotler (1997:186) "saluran pemasaran melaksanakan tugas memindahkan barang dari produsen ke konsumen". Hal ini mengatasi kesenjangan waktu, tempat dan pemilihan yang memisahkan barang dan jasa dari orang-orang yang membutuhkan atau menginginkannya. Kotler (1997:191) mengungkapkan bahwa : Anggota saluran pemasaran melaksanakan sejumlah fungsi utama: a. Informasi, yaitu pengumpulan dan penyebaran informasi pemasaran mengenai pelanggan, pesaing, serta pelaku dan kekuatan lain yang ada saat ini maupun yang potensial dalam lingkup pemasaran. b. Promosi, yaitu pengembangan dan penyebaran komunikasi persuasif yang dirancang untuk menarik pelanggan pada penawaran tersebut. c. Negosiasi, yaitu usaha untuk mencapai persetujuan akhir mengenai harga dan syarat lain sehingga transfer kepemilikan dapat dilakukan. d.Pemesanan, yaitu komunikasi dari para anggota saluran pemasaran ke produsen mengenai minat untuk membeli. e. Pembiayaan, yaitu perolehan dan pengalokasian dana yang dibutuhkan untuk membiayai persediaan pada berbagai tingkat saluran pemasaran. f. Pengambilan resiko, yaitu penanggungan resiko yang berhubungan dengan pelaksanaan fungsi saluran pemasaran tersebut. g. Pemilihan fisik, yaitu kesinambungan penyimpanan dan penggerak produk fisik dari bahan mentah sampai ke pelanggan akhir. h. Pembayaran, yaitu pembeli membayar tagihan ke penjual lewat bank dan institusi keuangan lainnya. i. Hak milik, yaitu transfer kepemilikan sebenarnya dari satu organisasi atau orang ke organisasi atau orang yang lain.

Menurut Alma (2003:59) mengungkapkan bahwa :people berarti orang yang melayani ataupun yang merencanakan pelayanan terhadap para 
konsumen. Karena sebagian besar jasa dilayani oleh orang maka orang tersebut perlu diseleksi, dilatih, dimotivasi sehingga dapat memberikan kepuasan terhadap pelanggan. Setiap karyawan harus berlomba-lomba berbuat kebaikan terhadap konsumen dengan sikap, perhatian, responsive, inisiatif, kreatif, pandai memecahkan masalah, sabar, dan ikhlas.

Kusmana dalam Alma (2003 : 22) menyatakan bahwa "aspek-aspek kepemimpinan yang dimiliki para administrator yang berupa kompetensi, wawasan dan kreativitas secara positif dan nyata mempengaruhi keadaan stabilitas dan tingkat akademik yang dipimpin administrator yang bersangkutan". Hurriyati (2005 :34) mengungkapkan bahwa : orang (people) adalah semua pelaku yang memainkan peranan dalam penyajian jasa sehingga dapat mempengaruhi persepsi pembeli. Elemen-elemen dari people adalah pegawai perusahaan, konsumen dan konsumen lain dalam lingkungan jasa. Semua sikap dan tindakan karyawan, bahkan cara berpakaian karyawan dan penampilan karyawan mempunyai pengaruh terhadap persepsi konsumen atau keberhasilan penyampaian jasa (service encounter).

Hurriyati (2005 37) menyatakan bahwa :elemen dari people ini memiliki 2 aspek yaitu: a) Service People Untuk organisasi jasa, service people biasanya memegang jabatan ganda, yaitu enmengadakan jasa dan menjual jasa tersebut. Melalui pelayanan yang baik, cepat, ramah, teliti dan akurat dapat menciptakan kepuasan dan kesetiaan pelanggan terhadap perusahaan yang akhirnya akan meningkatkan nama baik perusahaan. b) Customer Faktor lain yang mempengaruhi adalah hubungan yang ada diantara para pelanggan. Pelanggan dapat memberikan persepsi kepada nasabah lain, tentang kualitas jasa yang pernah didapatnya dari perusahaan. Keberhasilan dari perusahaan jasa berkaitan erat dengan seleksi, pelatihan, motivasi dan manajemen dari sumber daya manusia.

Boom\&Bitner dalam Kotler\&Armstrong (1997 : 58) mengungkapkan bahwa : physical evidence merupakan sarana fisik, lingkungan terjadinya penyampaian jasa, antara produsen dan konsumen berinteraksi dan setiap komponen lainnya yang memfasilitasi penampilan jasa yang ditawarkan. Pada sebuah lembaga pendidikan dan pelatihan tentunya yang merupakan physical evidence ialah gedung/bangunan, dan segala sarana dan fasilitas yang terdapat didalamnya.

Lovelock dalam Tjiptono (2008: 211) mengemukakan bahwa : perusahaan melalui tenaga pemasarnya menggunakan tiga cara dalam mengelola bukti fisik yang strategis, yaitu sebagai berikut: a. An Attention-Creating Medium
Perusahaan jasa melakukan differensiansi dengan pesaing dan membuat sarana fisik semenarik mungkin untuk menjaring pelanggan dari target pasar. b. As a Message-Creating Medium. Menggunakan simbol atau isyarat untuk mengkomunikasikan secara insentif kepada audiens mengenai kekhususan kualitas dari produk jasa. c. An Effect-Creating Medium Baju seragam yang berwarna, bercorak, suara dan desain untuk menciptakan sesuatu yang lain dari produk jasa yang ditawarkan. Dari teori tersebut diatas dapat penulis ambil kesimpulan bahwa untuk memasarkan produk yang bersifat jasa diperlukan fasilitas berpentuk fisik yang dapat menarik konsumen seperti ruangan untuk presentasi, warna serta mode pakaian yang sesuai dan bahasa komunikasi yang dapat mempengaruhi keinginan konsumen didalam membeli produk yang ditawarkan.

\section{METODE PENELITIAN.}

Penelitian ini menggunakan metode deskriptif dengan pendekatan kualitatif. Metode deskriptif dapat diartikan sebagai prosedur pemecahan masalah yang diselidiki dengan menggambarkan, melukiskan keadaan byek/obyek penelitian (seseorang, lembaga, masyarakat dan lain-lain) pada saat sekarang berdasarkan faktafakta yang tampak, atau sebagaimana adanya. Penelitian ini menggunakan perspektif pendekatan kualitatif. Menurut Denzin dan Lincon dalam Moleong ( 2006:5 ) menyatakan bahwa "Penelitian kualitatif adalah penelitian yang menggunakan latar alamiah dengan maksud menafsirkan fenomena yang terjadi dan dilakukan dengan jalan melibatkan berbagai metode yang ada".

Arikunto (1993:116) menyatakan “ Subyek penelitian atau sasaran penelitian adalah satuan tertentu yang diperhitungkan sebagai subyek penelitian". Dalam penelitian sosial subyek penelitian adalah manusia.Subyek penelitian dalam penelitian ini terdiri dari : Kepala Cabang PT. Prudential Pru Victory Kecamatan Sintang, Kepala Bagian Pemasaran Cabang PT. Prudential Pru Victory Kecamatan Sintang, Agen Cabang PT. Prudential Pru Victory Kecamatan Sintang, Nasabah Cabang PT. Prudential Pru Victory Kecamatan Sintang

Wawancara dalam penelitian ini akan dilakukan dengan menggunakan pedoman umum wawancara ini, interview, dilengkapi pedoman wawancara yang sangat umum dan mengisi kuesioner serta mencantumkan isu-isu yang harus diliput tanpa menentukan urutan pertanyaan 
bahkan mungkin tidak terbentuk pertanyaan yang eksplisit.Observasi. Dalam penelitian ini juga melakukan metode observasi. Observasi yang akan dilakukan adalah observasi terhadap subyek, perilaku subyek selama wawancara, interaksi subyek terhadap peneliti dan hal-hal yang dianggap relevan sehingga dapat memberikan data tambahan terhadap hasil wawancara. Studi Dokumentasi.Studi dokumentasi merupakan suatu teknik pengumpulan data dengan menghimpun damenganalisis dokuomen-dokumen baik secara tertulis, gambar maupun elektronik. Dukomen yang telah diperoleh kemudian dianalisis (diuraikan) dibandingkan dan dipadukan membentuk satu hasil kajian yang sistematis, terpadu dan utuh.

Dalam mengumpul data-data penulis membutuhkan alat bantu (instrumen penelitian). Dalam penelitian ini peneliti menggunakan 3 alat bantu yaitu :Pedoman wawanca. Pedoman wawancara digunakan agar wawancara yang dilakukan tidak menyimpang dari tujuan penelitian. Pedoman ini disusun berdasarkan tujuan penelitian dan berdasarkan dengan teoriteori yang berkaitan dengan masalah yang diteliti.

Pedoman Observasi. Pedoman observasi digunakan agar peneliti dapat melakukan pengamatan sesuai dengan tujuan penelitian. Pedoman observasi disusun berdasarkan hasil observasi terhadap prilaku subyek selama wawancara dan observasi terhadap lingkungan atau setting wawancara serta pengaruhnya terhadap perilaku subyek dan informasi yang muncul pada saat berlangsungnya wawancara.

Dokumentasi.Pengumpulan dokumentasi penulis memerlukan dokumen-dokumen penting yang mempunyai hubungan dan ada keterkaitan dengan topik penelitian ini. Dalam menganalisa penelitian kualitatif terdapat beberapa tahapan tahapan yang perlu dilakukan, diantaranya $: 1$. Mengorganisasikan Data.Peneliti mendapatkan data langsung dari subjek melalui wawancara mendalam (indepth), dimana data tersebut direkam dengan menggunakan alat perekam seperti $\mathrm{Hp}$ dan dibantu dengan alat tulis lainnya. Kemudian dibuatkan transkrip dengan mengubah hasil wawancara dari bentuk rekaman menjadi bentuk tertulis secara rinci. Data yang telah didapat dibaca, dianalisa berulang -ulang agar penulis mengerti serta memahami benar-benar data atau hasil yang telah didapatkan. Pengelompokan berdasarkan Kategori, Tema dan pola jawaban Pada tahap ini dibutuhkan pemahaman serta pengertian yang mendalam terhadap data, perhatian yang penuh dan keterbukaan terhadap hal-hal yang muncul diluar apa yang ingin digali. kode dan penjelasan singkat kemudian dikelompokan atau dikategorikan berdasarkan kerangka analisis yang telah dibuatkan.

Pada penelitian ini, analisis dilakukan terhadap permasalahan yang diteliti. Peneliti menganalisis hasil wawancara berdasarkan pemahaman terhadap hal-hal yang diungkapkan oleh responden. Data yang telah dikelompokan tersebut untuk dipahami dan dimengerti secara konferehensif oleh peneliti sehingga peneliti dapat menangkap pengalaman, permasalahan dan dinamika yang terjadi sebenarnya pada subjek yang diteliti. 2. Penyesuaian antara permasalahan yang ada terhadap data. Setelah mengkategori pola data tergambar dengan jelas, Peneliti menyesuaikan data tersebut terhadap permasalahan yang dikembangkan dalam data tersebut terhadap permasalahan yang dikembangkan dalam penelitian ini dengan cara meninjaukan kembali berdasarkan Kajian Pustaka yang telah dipaparkan dalam bab II sehingga ada kesesuaian antara Kajian Pustaka dengan hasil yang dicapai. 3. Mencari Alternatif Penjelasan tentang Data.

Penelitian ini berlokasi di Cabang PT. Prudential Pru Victory Kecamatan Sintang, Kabupaten Sintang. Alasan penulis mengambil lokasi penelitian ini adalah: Alasan metodologis. Lokasi ini dipilih karena dari aspek biaya serta jarak tempuh terjangkau oleh penulis, Lokasi penelitian ini juga dianggap dapat memberikan ta data dan informasi yang diperlukan untuk penelitian ini. Alasan praktis.Dengan sudah banyaknya Perusahaan yang bergerak pada sektor asuransi di Kabupaten Sintang pada umumnya dan Kecamatan Sintang khususnya diharapkan Cabang PT. Prudential PrVictory Kecamatan Sintang memiliki strategi yang tepat didalam memasarkan produknya sehingga jumlah penjualan polis asuransi semakin meningkat setiap tahunnya.

\section{HASIL DAN PEMBAHASAN}

\section{Produk (Product).}

Berdasarkan hasil wawancara penulis dengan Kabag. Pemasaran cabang PT. Prudential Pru. Victory Kecamatan Sintang Kabupaten Sintang diperoleh informasi bahwa dalam meningkatkan penjualan sebuah produk asuransi dibutuhkan adanya strategi pemasaran. Bahkan suatu produk tidak ada yang membelinya jika tidak dikenal oleh calon nasabah dan nasabah tidak mengetahui kegunaan serta keunggulan suatu produk serta dimana produk asuransinya

diperoleh. Untuk itulah calon nasabah asusransi yang dijadikan sasaran produk perlu diberikan penjelasan yang rinci. Apabila strategi pemasaran yang dijalankan baik, maka target penjualanpun akan semakin meningkat sesuai kemampuan agen 
pemasaran didalam menjalankan strategi pemasaran yang telah perusahaan tetapkan.

Ada berberapa jenis produk asuransi yang ditawarkan oleh Kabag. Pemasaran cabang PT. Prudential Pru. Viktory Kecamatan Sintang Kabupaten Sintang yang selama ini penjualannya banyak dibeli oleh calon nasabah karena memiliki berbagai keunggulan serta telah dikenali oleh sebagian masyarakat Kecamatan Sintang khususnya dan Masyarakat Kabupaten Sintang pada umumnya yaitu produk asuransi jiwa : yang pertama PRU Link Assurance Accountc(PAA) yaitu asuransi jiwa yang dikaitkan dengan investasi yang memberikan perlindungan asuransi jiwa sekaligus keuntungan berinvestasi dan juga telah dirancangkan untuk memberikan fleksibilitas yang dapat memenuhi kebutuhan dalam setiap tahapan kehidupan nasabah. Kedua yaitu PRU Link Investor Account (PIA) adalah produk unit Link dengan pembayaran premi sekaligus yang menawarkan berbagai pilihan dana Investasi. Ketiga yaitu produk asuransi PRU Link Fixed Pay $(P F P)$ produk unit Link yang dirancang untuk memberikan fleksibilitas yang dapat memenuhi berbagai kebutuhan disetiap kehidupan nasabah, dengan manfaat kematian yang dijamin(sesuai dengan ketentuan berlaku) dan pilihan priode pembayaran premi yang pasti. Dan produk yang keempat adalah PRU Syariah adalah produk asuransi yang dikaitkan dengan investasi berbasis syariah. Dari keempat jenis produk asuransi dimaksudkan memiliki masing-masing manfaat yang berbeda diantaranya ada yang hanya melindungi dari aspek perlindungan ekonomi terhadap keluarga yang ditinggalkan jika nasabah yang bersangkutan meninggal dunia (murni asuransi jiwa). Dan ada juga produk asuransi jiwa yang sekaligus mengcover biaya pengobatan nasabah apbila mengalami sakit saat masa pertanggunganpertanggungan masih berjalan/ berlaku termasuk pertanggungan penyakit tetap atau tetap total serta manfaat perlindungan yang dapat diwariskan pada keluarga tertentu jika nasabah telah meninggal dunia.

Cabang PT. Prudential Pru Viktory Kecamatan Sintang tidak memasarkan semua jenis asuransi produk perusahaan dikarenakan menyesuaikan keadaan tingkat ekonomi dan kebutuhan konsumen yang ada di kecamatan Sintang khususnya serta Kabupaten Sintang pada umumnya.Maksud dari penyesuaian kebutuhankonsumen yaitu pada setiap produk asuransi jiwa milik PT. Prudential seperti produk PRU Link Assurance Accountc(PAA), PRU Link Investor Account (PIA), PRU Link Fixed Pay (PFP) dan PRU Syariah memiliki manfaat tambahan yang bergandengan dengan produk tersebut seperti manfaat perlindungan kesehatan, manfaat untuk warisan dan sakit kritis yang diluar manfaat pokonya yakni asuransi jiwa nasabah. Diantara keempat produk yang dijadikan unggulan untuk dipasarkan selama ini di Kabupaten Sintang, asuransi jiwa yang memiliki manfaat dana warisan terbanyak polis terjual yaitu sebesar 116 polis, dan keduanya yakni asuransi jiwa yang digandengkan dengan produk tambahan(perlindungan kesehatan) yang banyak diminati oleh calon nasabah, polis terjual sebanyak 107 polis dan urutan ketiganya adalah asuransi jiwa yang ada manfaat tambahan berupa perlindungan komplet sebesar 68 polis. Sedangkan asuransi jiwa yang digandengkan dengan manfaat produk tambahan lainnya seperti perlindungan untuk sakit kritis 50 polis serta asuransi keselakaan 48 polis.

Selanjutnya berdasarkan hasil wawancara penulis dengan Kabag. Pemasaran cabang PT. Prudential Pru Viktory Kecamatan Sintang diperoleh informasi bahwa dari beberapa produk unggulan yang dipasarkan tersebut diatas selama ini hingga Desember tahun 2017 maka cabang PT. Prudential Pru Viktory Kecamatan Sintang telah dapat menjualkan polis dari keempat produk tersebut diatas sebanyak 389 polis. Dari 4 (Empat) jenis asuransi yang menjadi unggulan cabang PT. Prudential Pru Viktory Kecamatan Sintang yang dipasarkan di Kabupaten Sintang semuanya memiliki kemampuan bersaing di pasaran terhadap asuransi pesaing di Kabupaten Sintang pada tahun 2017 dengan kontribusi penjualannya mencapai 389 Polis bila dibandingkan pada tahun 2015 sebesar 251 polis dan pada tahun 2016 ada 298 polis. Dengan hanya peningkatan penjualan polis dari tahun ketahun dimaksud maka menunjukan produk asuransi jiwa yang dipasarkan oleh cabang PT. Prudential Pru Viktory Kecamatan Sintang memiliki kemampuan bersaing terhadap produk asuransi lain di Kabupaten Sintang hingga tahun

Selain faktor keunggulan masing-masing produk yang dimiliki dan dipasarkan oleh cabang PT. Prudential Pru Viktory Kecamatan Sintang, yang menjadi penentu pengambilan keputusan calon nasabah didalam pembelian produk asuransi yang ditawarkan oleh perusahaan ituyaaktor pengenalan dan penjelasan tentang roduk yang lebih rinci yang dilakukan oleh agent asuransi cabang PT. Prudential Pru Viktory Kecamatan Sintang. Karena kecenderungan calon nasabah tidak membeli produk yang ditawarkan oleh agen asuransi karena calon nasabah tidak menjelaskan manfaat asuransi itu sendiri kepada calon nasabah 
secara lebih rinci selain juga ada factor lainnya seperti factor ekonomi dan factor image lainnya yang selama ini dialami oleh para calon nasabah yang diakibatkan oleh pengetahuan calon nasabah yang kurang memadai terhadap proses serta manfaat asuransi jiwa untuk kepentingan calon nasabah bila telah memiliki asuransi jiwa termasuk manfaat tambahan lainnya yang melekat pada asuransi jiwa tersebut.

Berdasarkan hasil wawancara kepada Kabag. Pemasaran cabang PT. Prudential Pru Viktory Kecamatan Sintang tersebut diatas maka dapat penulis ambil sebuah kesimpulan sementara yaitu bahwa produk asuransi yang manfaatnya sesuai dengan kebutuhan dan keinginan calon konsumen/nasabah merupakan salah satu strategi yang positif dan merupakan faktor pendorong didalam meningkatnya penjualan polis oleh perusahaan asuransi cabang PT. Prudential Pru Viktory Kecamatan Sintang. Selain itu penjelasan yang lebih rinci tentang manfaat produk asuransi oleh agen/konsultan kepada calon konsumen/calon nasabah dapat menambah ketertarikan didalam membeli polis asuransi karena nasabah lebih memahami manfaat perlindungan asuransi dalam kehidupandirinya maupun keluarganya dikemudian hari.

\section{Harga (Price).}

Berdasarkan hasil wawancara penulis dengan pimpinan cabang PT. Prudential Pru Viktory Kecamatan Sintang diperoleh informasi bahwa perusahaan melalui agen yang setiap harinya di lapangan agar menjelaskan biaya premi setiap jenis asuransi yang ditawarkan setelah terlebih dahulu menjelaskan manfaat perlindungan asuransi untuk calon nasabah sehingga semua calon nasabah yang mengambil keputusan untuk membeli polis asuransinya pada cabang PT. Prudential Pru Viktory Kecamatan Sintang tidak kecewa dan merasa puas dengan manfaat yang dimiliki serta memahami dengan rinci tentang keuntungan mengambil jenis asuransi yang akan dibeli nasabah serta sesuai dengan kebutuhan yang mereka inginkan.

Selain itu pentingnya calon nasabah mengerti, memahami besaran premi asuransi yang mesti mereka bayarkan baik setiap bulan, triwulan, semester maupun yang bersifat pembayaran setiap tahun agar para calon nasabah dapat membeli polis asuransi dengan mempertimbangkan penghasilan serta pendapatannya. Dengan demikian resiko kegagalan pembayaran ansuran asuransinya tidak mengalami kendala selama masa pembayaran berlangsung. Selanjutnya berdasarkan hasil wawancara dengan Kabag. Pemasaran cabang PT. Prudential Pru Viktory Kecamatan Sintang diperoleh informasi bahwa pemasaran produk asuransi di Kabupaten Sintang dilakukan disemua tempat dan tidak memandang tingkat besar kecilnya pendapatan masyarakat secara umum. Hal ini disebabkan perusahaan memiliki berbagai jenis produk dan sistem pembayaran yang dapat dijangkau oleh calon nasabah sebagai contoh yaitu produk asuransi Prudential memiliki berbagai tingkat besar kecilnya perlindunganjiwa seseuai dengan uang pertanggungan yang diinginkan oleh calon nasabah secara ekonomi baik itu jenis asuransi jiwa murni maupun asuransi jiwa yang telah didampingi oleh manfaat tambahan seperti biaya rawat inap nasabah di rumah sakit dan manfaat tambahan bagi nasabah bila terjadi kecelakaan yang berakibatkan cacat tetap sebagian maupun cacat tetap total. Selain dari pola pemasaran polis asuransi tersebut diatas cabang PT. Prudential Pru Viktory Kecamatan Sintang juga selama ini memasarkan produk asuransi berdasarkan tingkat kualitas produk itu sendiri. Maksudnya yaitu penjualan produk yang memiliki manfaat perlindungan secara ekonomi lebih besar dan maksimal kepada setiap calon nasabah sehingga jika terjadi sesuatu kepada nasabah yang bersangkutan tidak lagi harus mengeluarkan dana yang besar secara pribadi di rumah sakit karena sudah ada perlindungan biaya yang ditanggung oleh perusahaan PT. Prudential.

Setiap agen diharapkan dapat menjelaskan besaran premi, masa waktu pembayaran premi serta manfaat asuransi yang dipilh oleh nasabah / konsumen. Dengan demikian nasabah memiliki keinginan yang kuat untuk membeli polis asuransi prudential sesuai dengan kebutuhan dan tingkat kemampuan ekonomi yang dimilikinya.

\section{Promosi (Promotion).}

Berdasarkan hasil wawancara penulis dengan Kabag. Pemasaran cabang PT. Prudential Pru. Victory Kecamatan Sintang Kabupaten Sintang didapatkan informasi bahwa promosi dilakukan melalui berbagai cara yang dapat terakses kepada konsumen yang lebih luas dan cepat seperti melalui media elektronik seperti facebook dan whatshap serta ada juga promosi dilakukan masih bersifat konvensional yaitu agen asuransi menemui konsumen secara langsung dengan mendatangi konsumen dari rumah ke rumah (door to door) secara acak di setiap kecamatan di Kabupaten Sintang terutama wilayah yang telah dijadikan target promosi oleh cabang PT. Prudential Pru. 
Victory Kecamatan Sintang Kabupaten Sintang yang dapat dijangkau kengan kendaraan baik roda empat maupun kendaraan roda dua. Selain itu promosi juga dilakukan oleh group agen perusahaan dengan sistem pertemuan secara berkelompok baik kepada perusaahaanperusahaan, organisasi sosial maupun di instansiinstansi pemerintahan di Kabupaten Sintang. Selanjutnya hasil wawancara penulis dengan Kabag. Pemasaran cabang PT. Prudential Pru. Victory Kecamatan Sintang Kabupaten Sintang diperoleh informasi bahwa Promosi produk asuransi yang dilakukan oleh pihak perusahaan melalui agen-agen sebagai tenaga pemasaran tidak untuk semua produk yang ada pada cabang PT. Prudential Pru. Victory Kecamatan Sintang Kabupaten Sintang. Hal ini dikarenakan menyesuaikan situasi dan kondisi tingkat pendapatan konsumen dan proyeksi kebutuhan konsumen di daerah setempat. Selain itu itu promosi juga dilakukan dengan melihat daerah kecamatan yang dianggap potensial dapat membeli polis asusransi seperti kecamatan-kecamatan di Kabupaten yang memiliki perusahaan perkebunan sawit dan perusahaan lain yang berpotensi membutuhkan perlindungan asuransi.

Promosi yang dilakukan oleh cabang PT. Prudential Pru. Victory Kecamatan Sintang Kabupaten Sintang melalui agen-agen asuransi pada tahun 2017 telah dapat meningkatkan penjualan polis asuransinya terutama pada jenis asuransi jiwa, asuransi tambahan seperti asuransi penyakit kritis, asuransi untuk dana warisan serta asuransi melalui kartu kesehatan (Hs).

Berdasarkan hasil wawancara kepada Kabag Pemasaran cabang PT. Prudential Pru Viktory Kecamatan Sintang tersebut diatas maka dapat penulis ambil sebuah kesimpulan sementara bahwa perusahaan melakukan promosi produk asuransinya melalui tiga pola utama yaitu promosi produk melalui dari rumah ke rumah (door to door) yang dilakukan oleh agen/konsultan, kedua yaitu dengan mengadakan pertemuan dengan kelompok orang baik itu di perusahaan-perusahaan maupun di kantor-kantor instansi pemerintah serta promosi melalui media online berupa Facebook, Whatshaf dan web milik perusahaan serta agen/konsultan. Dengan menggunakan pola promosi pemasaran seperti inicukup efektif didalam meningkatkan penjualan polis asuransi setiap tahunnya bagi perusahaan cabang PT. Prudential Pru. Viktory Kecamatan Sintang hingga tahun 2018.

\section{Tempat (Place).}

Berdasarkan hasil wawancara penulis dengan Staf bagian pemasaran cabang PT. Prudential Pru. Victory Kecamatan Sintang Kabupaten Sintang diperoleh informasi bahwa selama ini hingga tahun 2018 penjualan polis asuransi oleh pihak perusahaan tidak harus dilakukan di Kantor karena setiap agen telah memiliki aplikasi di laptop atau gadgetnya masingmasing tentang data untuk penjualan semua jenis polis asuransi prudential.

\section{Orang (People)}

Berdasarkan hasil wawancara penulis terhadap Agen/Konsultan cabang PT. Prudential Pru. Victory Kecamatan Sintang Kabupaten Sintang diperoleh informasi bahwa dalam memasarkan produk asuransi milik perusahaan cabang PT. Prudential Pru. Victory Kecamatan Sintang Kabupaten Sintang lebih mengutamakan agen/konsultan bila dibandingkan dengan pemasaran lewat online. Hal ini disebabkan pertama pemasaran lewat internet online (media elektronik) di Kabupaten Sintang masih terbatasnya akses internet yang dapat dijangkau oleh konsumen oleh sebab itu perusahaan lebih mengutamakan melalui agen/konsultan untuk memasarkan produk asuransi (polis).hingga sudah mampu memahami dan mengerti tentang produk asuransi yang dipasarkan serta strategi pemasran yang disampaikan oleh perusahaan. Agen asuransi yang telah dinyatakan diterima untuk memasarkan produk asuransi yang diberikan dedengan berbagai motivasi kerja berupa gaji, bonus dan reward bagi yang berprestasi sehingga agen/konsultan lebih terpacu didalam penjualan produk asuransi dalam upaya meningkatkan penjualan polis setiap bulan dan setiap tahun. Selain itu juga agen/konsultan sebelum memasarkan produknya diwajibkan mengikuti pelatihan tentang produk agar memahami serta mengerti manfaat produk asuransi yang dipasarkan.

Berdasarkan hasil wawancara penulis terhadap Agen/Konsultan cabang PT. Prudential Pru. Victory Kecamatan Sintang Kabupaten Sintang maka dapat penulis ambilakan suatu kesimpulan sementara bahwa pemasaran produk dilakukan melalui tenaga agen/konsultan yang direkrut kemudiaan dilakukan test seleksi. Yang lulus memenuhi syarat diberikan pelatihan (training) pengetahuan tentang produk asuransi oleh cabang PT. Prudential Pru Viktory Kecamatan Sintang. Sedangkan untuk memotivasi agen/ konsultan tersebut diberikan gaji pokok serta insentif, bonus, jika tercapainya target penjualan 
bulanan. Dengan demikian setiap bulan dan setiap tahun cabang PT. Prudential Pru Viktory Kecamatan Sintang mengalami peningkatan penjualan polis asuransi hingga dari tahun 2016 hingga tahun 2018.

\section{Sarana Fisik (Fhysical Evedence)}

Sarana fisik seperti kantor sebuah perusahaan kerap kali sebagai fasilitas tempat pemberian pelayanan kepada konsumen/nasabah namun tidak demikian perusahaan asuransi jiwa cabang PT. Prudential Pru. Victory Kecamatan Sintang Kabupaten Sintang, Kantor hanya merupalan tempat kegiatan karyawan staf yang khusus memberikan pelayanan administrasi kepada aktifitas agen sehari-hari.

Berdasarkan hasil wawancara penulis terhadap Agen/Konsultan asuransi cabang PT. Prudential Pru. Victory Kecamatan Sintang Kabupaten Sintang diperoleh informasi tentang penggunaan saran fisik kantor cabang tidak digunakan untuk pemberian pelayanan kepada konsumen/nasabah melainkan hanya dimanfaatkan untuk pimpinan, tenaga staf administrasi serta agen untuk melakukan pertemuan rapat atau breafing setiap pagi sebelum berangkat ke lapangan dan setelah datang dari memasarkan produk asuransi dari lapangan guna mengirimkan hasil pemasaran produk asuransi milik nasabah serta laporan hasil pemasaran setiap hari secara kontinyu. Sedang kan Fasilitas kantor beserta instrument lainnya dalam kantor sebagai penunjang kegiatan pemasaran dan memproses hasil penjualan agar dapat diteruskan menjadi sebuah perjanjian dalam bentuk polis oleh perusahaan cabang PT. Prudential Pru. Victory Kecamatan Sintang Kabupaten Sintang.

Berdasarkan hasil wawancara penulis terhadap Agen/Konsultan dan nasabah cabang PT. Prudential Pru. Victory Kecamatan Sintang Kabupaten Sintang maka dapat penulis ambilakan suatu kesimpulan sementara bahwa cabang PT. Prudential Pru Viktory Kecamatan Sintang memiliki kantor tersendiri dengan fasilitas kegiatan operasional perusahaan namun fasilitas fisik ini tdk sepenuhnya digunakan untuk kegiatan pemasaran maupun penjualan oleh agen/konsultan hal ini dikarenakan kantor hanya sebatas tempat pertemuan pimpinan cabang dengan staf dan agenagen asuransinya sebelum dan sesudah agen/ konsultan pulang dari lapangan memasarkan produk asuransi. Selain itu kantor cabang cabang PT. Prudential Pru Viktory Kecamatan Sintang berfungsi sebagai tempat mengurusi administrasi asuransi nasabah untuk tahap selanjutnya.

\section{KESIMPULAN DAN SARAN}

Agen asuransi Cabang PT. Prudential Pru. Victory kecamatan Sintang dalam upaya meningkatkan penjualan polis asuransi yakni dengan salah satu strateginya menjelaskan manfaat asuransinya yang lebih rinci Kepada calon nasabah/konsumen disesuaikan dengan kebutuhan dan keinginan calon konsumen/nasabah tersebut. Dengan penjelasan manfaat asuransi yang lebih inci dapat menambah ketertarikan pemahaman calon nasabah atas pentingnya asuransi untuk perlindungan ekonomi diri maupun keluarganya dikemudian hari sehingga mengambil suatu keputusan yang tepat didalam membeli polis asuransi yang ditawarkan oleh agen cabang PT. Prudential Pru. Viktory Kecamatan Sintang. Setiap agen telah dapat menjelaskan besaran premi, masa waktu pembayaran premi serta manfaat asuransi yang dipilh oleh nasabah/ konsumen. Dengan demikian nasabah memiliki keinginan yang kuat untuk membeli polis asuransi prudential sesuai dengan tingkat kemampuan ekonomi yang dimilikinya. Perusahaan melakukan promos i produk asuransinya melalui tiga pola utama yaitu promosi produk melalui dari rumah ke rumah (door to door) yang dilakukan oleh agen/konsultan, kedua yaitu dengan mengadakan pertemuan dengan kelompok orang baik itu di perusahaan-perusahaan maupun di kantor- kantor instansi pemerintah serta promosi melalui media online berupa Facebook, Whatshaf dan web milik perusahaan serta agen/konsultan. Dalam menjualkan produk asuransinya agen/konsultan perusahaan prudential Sintang tidak terpusat dikantor cabang tempatnya bekerja Karena closing penjualan polis dapat dilakukan disemua tempat yang terakses dengan internet. Selain itu juga tergantung kepada kkeinginan nasabah/ konsumen dan agen/konsultan. Dalam hal ini transaksi jual beli asuransi semuanya telah dapat dilakukan secara tidak memberatkan nasabah dari aspek biaya biaya maupun waktu untuk menuju Kantor cabang PT. Prudential Pru Viktory Kecamatan Sintang. 5.Pemasaran produk dilakukan melalui tenaga agen/konsultan yang direkrut kemudiaan dilakukan test seleksi. Yang lulus memenuhi syarat diberikan pelatihan (training) pengetahuan tentang produk asuransi oleh cabang PT. Prudential PrPru.Viktory Kecamatan Sintang. Sedangkan untuk memotivasi agen/konsultan tersebut diberikan gaji pokok serta insentif, bonus, jika tercapainya target penjualan bulanan. Cabang PT. Prudential Pru. Viktory Kecamatan Sintang memiliki kantor tersendiri dengan fasilitas kegiatan operasional perusahaan namun fasilitas fisik ini tidak 
sepenuhnya digunakan untuk kegiatan pemasaran maupun penjualan oleh agen/konsultan hal ini dikarenakan kantor hanya sebatas tempat pertemuan pimpinan cabang dengan staf dan agenagen asuransinya sebelum dan sesudah agen/ konsultan pulang dari lapangan memasarkan produk asuransi.

Disarankan Produk asuransi yang ditawarkan oleh perusahaan PT. Prudential dimasa yang akan datang tidak lagi selalu ada kesamaan manfaat seperti asuransi milik kompetiter lainnya yang hanya melindungi jiwa serta aspek kesehatan nasabah maupun nilai investasi jangka panjang namun bagaimana sebuah perusahaan asuransi dapat menciptakan serta memasarkan produk asuransi perpaduan antara perlindungan jiwa secara ekonomi tertanggung, keluarga maupun asuransi yang diakibatkan oleh musibah alam serta asuransi kebakaran dijadikan satu polis sehingga nasabah tidak diperlukan memiliki banyak polis asuransi dan lebih efisien dari aspek jumlah premi maupun resiko mangkrak didalam pembayaran premi untuk selanjutnya. Sebaiknya untuk agen/konsultan asuransi perusahaan PT. Prudential dimasa akan datang dapat merubah status agen/karyawan yang selama ini masih bersifat mitra kerja dapat dijadikan Karyawan tetap seperti lembaga keuangan lainnya seperti perbankan. Dengan demikian agen/konsultan asuransi lebih termotivasi dan konsentrasi ikut andil bersama pemilik perusahaan didalam pengembangan usaha dengan memaksimalkan penjualan polis asuransi perusahaan untuk kelangsungan kehidupan perusahaan itu sendiri dalam jangka panjang dan dapat terus membantu memberikan bantuan pelayanan klaim asuransi nasabah jika ada permasalahan dikemudian hari terutama nasabah yang membeli polis lewat agen/konsultan yang bersangkutan.

\section{DAFTAR PUSTAKA}

Alma, Buchari. 2003. Manajemen Pemasaran dan Pemasaran Jasa. CV. Alfabeta: Bandung.

Arikunto, S.1993. Metode Penelitian Kualitatif. Yogyakarta : Bumi Aksara.

Denzin, N. K. dan Lincoln, Y. S. (2006). Pustaka

Hurriyati, Ratih (2005), Bauran Pemasaran dan Loyalitas Konsumen, Bandung. Alfabeta.

Kotler, P. ( 1997 ). Manajemen Pemasaran ( Terjemahan ). PT. INDEKS Kelompok Media, Jakarta.

Kotler, (2001). Prinsip-prinsip pemasaran, Edisi keduabelas, Jilid 1. Jakarta: Erlangga.

Kotler, Philip. 1997. Manajemen Pemasaran di Indonesia: Analisis, Perencanaan, Implementasi dan Pengendalian. Salemba Empat. Jakarta.N

Stanton, William J. 2001. Prinsip Pemasaran. Erlangga. Jakarta.

Tjiptono, F. (2008). Strategi Pemasaran Edisi III. PT. ANDI, Yogyakarta. 